Article

\title{
Growth and Functionality of Cells Cultured on Conducting and Semi-Conducting Surfaces Modified with Self-Assembled Monolayers (SAMs)
}

\author{
Rajendra K. Aithal ${ }^{1}$, Amber T. Doss ${ }^{2}$, Deepak P. Kumaraswamy ${ }^{1,3}$, David K. Mills ${ }^{2,3}$ and \\ Debasish Kuila 1,4,* \\ 1 Institute of Micromanufacturing, Louisiana Tech University, Ruston, LA 71272, USA; \\ rajaithal@gmail.com (R.K.A.); dkswamy@gmail.com (D.P.K.) \\ 2 School of Biological Sciences, Louisiana Tech University, Ruston, LA 71272, USA; \\ Amber.Doss@genzyme.com (A.T.D.); dkmills@latech.edu (D.K.M.) \\ 3 Center for Biomedical Engineering and Rehabilitation Science, Louisiana Tech University, \\ Ruston, LA 71272, USA \\ 4 Department of Chemistry, Department of Nanoengineering, Joint School of Nanoscience and \\ Nanoengineering, North Carolina A \& T State University, Greensboro, NC 27411, USA \\ * Correspondence: dkuila@ncat.edu; Tel.: +1-336-285-2243; Fax: +1-336-334-7124 \\ Academic Editor: James Kit-hon Tsoi \\ Received: 22 November 2015; Accepted: 28 January 2016; Published: 18 February 2016
}

\begin{abstract}
Bioengineering of dermal and epidermal cells on surface modified substrates is an active area of research. The cytotoxicity, maintenance of cell phenotype and long-term functionality of human dermal fibroblast (HDF) cells on conducting indium tin oxide (ITO) and semi-conducting, silicon ( $\mathrm{Si}$ ) and gallium arsenide (GaAs), surfaces modified with self-assembled monolayers (SAMs) containing amino $\left(-\mathrm{NH}_{2}\right)$ and methyl $\left(-\mathrm{CH}_{3}\right)$ end groups have been investigated. Contact angle measurements and infrared spectroscopic studies show that the monolayers are conformal and preserve their functional end groups. Morphological analyses indicate that HDFs grow well on all substrates except GaAs, exhibiting their normal spindle-shaped morphology and exhibit no visible signs of stress or cytoplasmic vacuolation. Cell viability analyses indicate little cell death after one week in culture on all substrates except GaAs, where cells died within $6 \mathrm{~h}$. Cells on all surfaces proliferate except on GaAs and GaAs-ODT. Cell growth is observed to be greater on SAM modified ITO and Si-substrates. Preservation of cellular phenotype assessed through type I collagen immunostaining and positive staining of HDF cells were observed on all modified surfaces except that on GaAs. These results suggest that conducting and semi-conducting SAM-modified surfaces support HDF growth and functionality and represent a promising area of bioengineering research.
\end{abstract}

Keywords: human dermal fibroblasts; self-assembled monolayer; amino group; proliferation; GaAs; ITO; conducting surface

\section{Introduction}

Engineered cell-tissue composites that mimic skin have been developed for use as an in vitro system in sensitivity assays for potential skin-irritant compounds, drug permeation studies, cytotoxicity tests, and detection of chemical warfare threats [1-3]. A major objective of bioengineered skin is the need to enhance functionality and responsiveness and to improve the methodology for irritant and toxic reactions, reduce the costs of testing, and facilitate decision making [4].

Fibroblasts play a major role in building and maintaining the extracellular matrix (ECM) in the dermis of adult skin. Dermal ECM consists principally of fibroblasts, connective tissue fibers such as 
collagen and glycoproteins, such as fibronectin and proteoglycan, that provide mechanical support, present sites for cell anchorage and form interfaces between distinct cell types within connective tissues. Collagen and fibronectin can modulate several physiological and pathological processes including tissue repair and wound healing [5]. In addition, the organization of the fibronectin matrix, acting as an adhesive linker, regulates the composition and stability of the ECM. Fibroblasts are anchorage-dependent cells; hence, it is very important that the surface on which they are cultured have properties that support attachment [6,7].

Adhesion of cells to solid surfaces plays an integral role in several key cellular processes [8]. The initial attachment of a cell to a surface is by receptors in the cell membrane associated with the cytoskeleton, of which integrins are probably the most important. The attachment process also depends on the nature and conformation of adhesion proteins, such as fibronectin and vitronectin. Cell attachment is normally followed by reorganization of cytoskeletal actin, resulting in flattening and spreading of the cell and formation of focal contacts, replete with clustered integrins, which participate in cell signaling events and in regulating cell behavior. At each site of membrane-surface attachment, integrin receptors cluster and several intracellular signaling molecules are recruited. The signaling produced by integrin attachment to the ECM helps promote cell adhesion [8]. The adhesion of cells to the ECM and a host of subsequent signaling events are mediated by specific interactions between cell-surface receptors and ligands of the matrix [9].

The matrix plays an important role in cell adhesion. A matrix made of organic polymers is less attractive for the culture of HDF cells due to problems such as reorientation of surface elements on transfer to an aqueous media and the heterogeneous nature and difficulty in analyzing the morphological characteristics [10-12]. The design of surfaces to elicit specific cellular responses has, accordingly, been delayed. In this regard, SAMs have the capability to produce well-defined surfaces with known structures and properties that may be carefully regulated and manipulated [6,13-16]. Cell attachment may also be influenced by the increased absorption of fibronectin on SAMs [17] or binding of the protein in an orientation such that cell binding sites are accessible [18]. In this study, SAMs containing methyl and amino end groups on $\mathrm{Si}$, (silicon), GaAs (gallium arsenide) and 1-Octadecanethiol (ODT) surfaces were used to understand the influence of end group on fibroblast behavior with the objective to identify ideal substrate properties that either enhances or inhibits fibroblast adhesion, proliferation and functionality. These two end groups are typical functional groups in polymer substrates and represent hydrophobic and hydrophilic end groups that are commonly used in studies for protein adsorption and cell adhesion studies.

\section{Experimental Section}

\subsection{Materials}

Boron-doped (100)—oriented silicon wafers were purchased from Montco Silicon Technologies Inc., Semi-Insulating (100)—Undoped GaAs (gallium arsenide) wafers were purchased from American Xtal Inc. (Wilmington, DE, USA), 1-Octadecanethiol (ODT) coated glass slides $(2.5 \mathrm{~cm} \times 2.5 \mathrm{~cm} \times 0.1 \mathrm{~cm}$ ) were purchased from Delta Technologies Ltd. (Loveland, CO, USA) All the substrates were diced into approximately $1 \mathrm{~cm} \times 1 \mathrm{~cm}$ samples. Chemicals used were ODT (98\%, Aldrich, St. Louis, MO, USA), 3-(aminopropyl)triethoxysilane (APTES) (99\%, Sigma Aldrich, St. Louis, MO. USA) and Nanostrip (stabilized formulation of sulfuric acid and hydrogen peroxide compounds, Cyantek Corp. Fremont, CA, USA). All chemicals were used as received. Human dermal fibroblasts (HDFs) were isolated from adult skin and this primary cell line was obtained from Cascade Biologics (Portland, OR, USA). All cell culture plastics and reagents were obtained from Invitrogen (Carlsbad, CA, USA).

\subsection{Methods}

Preparation of Samples: Si samples were cleaned by sonication in acetone followed by ethanol for 5 min and finally rinsed in DI water and dried in $\mathrm{N}_{2}$. The samples were then immersed in a Nanostrip 
solution at $90{ }^{\circ} \mathrm{C}$ for $15 \mathrm{~min}$, rinsed in DI water and dried in $\mathrm{N}_{2}$. SAMs of APTES were formed by immersing the substrates in $1 \mathrm{mM}$ solution of APTES in ethanol for $1 \mathrm{~h}$, followed by rinsing with ethanol and DI water and finally drying in $\mathrm{N}_{2}$.

GaAs samples were similarly cleaned in acetone followed by ethanol for five minutes by ultrasonic agitation. Just before surface derivatization, the GaAs samples were immersed in $37 \% \mathrm{HCl}$ for one minute to remove oxide present on the surface, rinsed with DI water and dried in $\mathrm{N}_{2}$. SAM deposition on GaAs was performed in $5 \mathrm{mM}$ ODT solutions with the addition of $30 \%$ aqueous ammonia solution at $50{ }^{\circ} \mathrm{C}$ for $8 \mathrm{~h}$ after purging with $\mathrm{N}_{2}$. Physisorbed species were removed by carefully rinsing with ethanol followed by rinsing with DI water and drying in $\mathrm{N}_{2}$.

The ITO-coated slides were cleaned using sonication in toluene, acetone, and ethanol, each for five minutes, and then in DI water for $30 \mathrm{~min}$. The substrates were then rinsed, $\mathrm{N}_{2}$-dried, and used for SAM preparation. SAMs of ODT were formed on ITO by immersing the samples in the neat liquid for one hour, followed by ultrasonic agitation in ethanol, rinsing with ethanol and DI water and drying in $\mathrm{N}_{2}$. All SAM-modified samples were sterilized in 100\% ethanol for one day prior to cell culture studies.

\subsection{Characterization}

Contact Angle Measurements: Contact angle measurements were carried out using the sessile drop method on a Data Physics instrument contact angle goniometer. In this method, a drop of water $(0.5 \mu \mathrm{L})$ was suspended from a microliter syringe positioned above the sample stage. The syringe was moved towards the sample so that the water droplet makes contact with it. The syringe was then retracted, leaving the sample on the substrate. The image was then recorded using a CCD camera and the contact angle was measured using the software provided with the goniometer. Three readings of each sample were averaged to obtain the final value reported in all cases.

Infrared Spectroscopy: Reflection Absorption IR Spectra (RAIRS): (RAIRS) for SAMs on GaAs, ITO and Si were obtained from a Thermo Nicolet 470 FT-IR spectrometer (Thermo Scientific, Madison, WI, USA) equipped with a Smart Saga accessory containing a MCT (mercury-cadmium-telluride) detector. The chamber of the instrument was purged with $\mathrm{N}_{2}$ and the detector was kept cold using liquid $\mathrm{N}_{2}$. The spectra were recorded at a resolution of $4 \mathrm{~cm}^{-1}$ (512 scans) and the base line was corrected. The observed peaks were assigned to vibrations according to published FTIR studies on these or similar compounds.

\subsection{Cells Culture Studies}

Cell Culture: Human dermal fibroblasts (HDFs) were isolated from adult skin. This primary cell line was obtained from Cascade Biologics (Portland, OR, USA). HDF monolayer cultures were established by seeding cells recovered from cryopreservation at a density of $5.0 \times 103$ viable cells $/ \mathrm{cm}^{2}$ in four $25 \mathrm{~cm}^{2}$ tissue culture flasks. Cell cultures maintained in Dulbecco's Modified Eagle Medium (complete DMEM) supplements with 10\% fetal bovine serum and 1\% penicillin-streptomycin and the media was replace every three days until cultures were near confluency.

Cell Seeding: Prior to cell seeding, SAM substrates were washed three times with complete Dulbecco's modified eagle medium (DMEM). Established cultures of HDFs were washed twice with HBSS and then trypsinized with 1X trypsin (1 mL of trypsin and $99 \mathrm{~mL}$ of HBSS) and allowed to incubate for $8 \mathrm{~min}$. Detached HDFs were aspirated, placed in a $15 \mathrm{~mL}$ conical tube, and centrifuged for seven minutes at $1620 \mathrm{rpm}$. The supernatant was removed and the cells were re-suspended in complete DMEM. A 50- $\mu$ L cell suspension ( 400 cells: counted by hemocytometer) was then added to each substrate. HDFs were allowed to incubate for one hour on the substrates and then two milliliters of complete DMEM was added to each of the dishes. The media was replaced every two days with complete DMEM over the course of the experimental period. For all analyses on cell behavior triplicate cultures were used.

Cell Morphology: Morphological observations of HDFs cultured on SAM substrates were performed using the phase contrast mode of a Nikon ${ }^{\circledR}$ inverted fluorescent microscope equipped with 
a Nikon digital camera. The cells were observed after $24 \mathrm{~h}, 48 \mathrm{~h}$ and one week for any changes in morphology and visual indications of cellular damage.

Cell Viability: Cell viability was assessed using the LIVE/DEAD Cytotoxicity Kit from Molecular Probes. The dual fluorochrome assay described in the LIVE/DEAD Cytotoxicity kit was used to determine the viability of cells. This two-color fluorescence test that simultaneously identifies live and dead cells was used to determine cytotoxic effects.

Cell Proliferation: The MTT Cell Proliferation Assay Kit (Sigma, St. Louis, MO, USA) was used to quantify cellular viability and growth as a function of the mitochondrial activity. The mitochondrial dehydrogenase enzymes of viable cells cleave the tetrazolium ring of MTT to form purple MTT formazan crystals, which are soluble in $1 \mathrm{~N} \mathrm{HCl}$. The resulting purple solution can be spectrophotometrically analyzed. An increase in absorbance is directly proportional to the amount of formazan production and, hence, the number of viable cells.

Cell Phenotype: Immunocytochemical studies were performed on HDFs using the Vecastain ${ }^{\circledR}$ ABC kit (Vector Labs, Burlingame, CA. USA) and monoclonal antibodies raised against Type I collagen (CIC, Chemicon, Temecula, CA. USA). Cells were incubated with monoclonal antibodies (1:50) overnight followed by a biotinylated secondary antibody for $1 \mathrm{~h}$ and then labeled with avidin-biotin conjugated to peroxidase for $30 \mathrm{~min}$. Antigen-antibody complexes were visualized under the microscope after exposure to the substrate, DAB (diaminobenzidine) as directed by the manufacturer.

\section{Results and Discussion}

\subsection{Contact Angle Measurements}

Figure 1 shows the contact angles of different SAM-modified surfaces. An advancing contact angle in the range $22^{\circ}-24^{\circ}$ was observed for $\mathrm{Si}$ before $\mathrm{SAM}$ deposition due to $\mathrm{Si}-\mathrm{O}_{x}$ and $\mathrm{Si}-\mathrm{OH}$ groups, while an angle in the range of $34^{\circ}-36^{\circ}$ was observed for SAM formed with APTES. The surface of the $\mathrm{SAM}$ is hydrophilic due to its terminal amino $\left(-\mathrm{NH}_{2}\right)$ group.

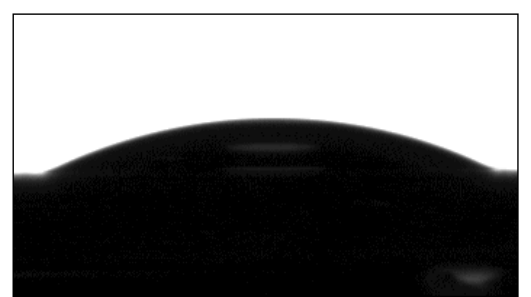

(a)

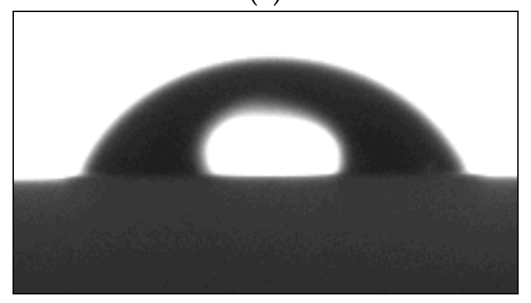

(c)

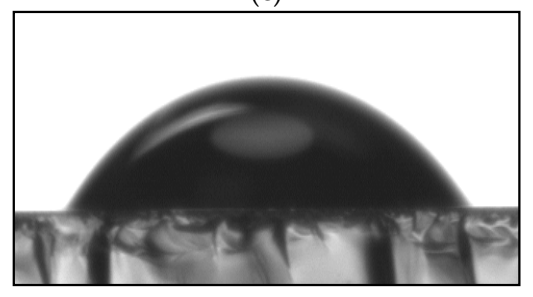

(e)

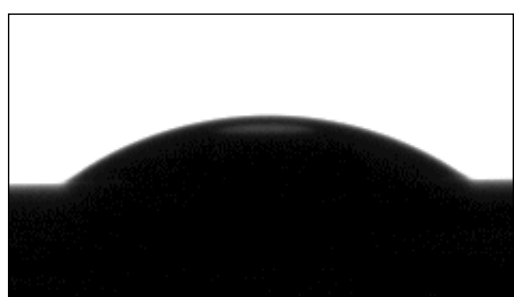

(b)

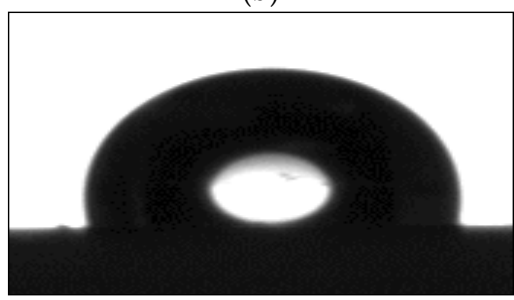

(d)

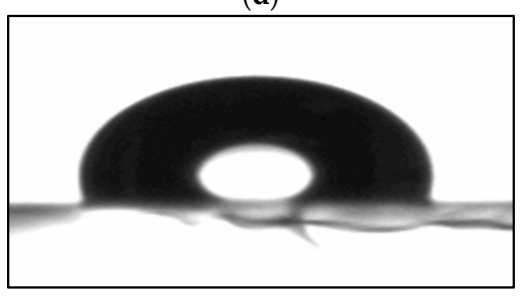

(f)

Figure 1. Contact angle measurements of (a) Si $\left(22^{\circ}-24^{\circ}\right)$; (b) Si-APTES $\left(34^{\circ}-36^{\circ}\right)$; (c) GaAs $\left(75^{\circ}-77^{\circ}\right.$ ); (d) GaAs-ODT $\left(102^{\circ}-105^{\circ}\right)$; (e) ITO $\left(40^{\circ}-45^{\circ}\right)$ and (f) ITO-ODT $\left(102^{\circ}-105^{\circ}\right)$. 
Advancing contact angle in the range of $75^{\circ}-77^{\circ}$ was observed for GaAs and $40^{\circ}-45^{\circ}$ for ITO, while contact angle in the range $102^{\circ}-105^{\circ}$ was observed after SAM deposition of ODT. ITO-ODT and GaAS-ODT substrates are highly hydrophobic due to the presence of methyl $\left(-\mathrm{CH}_{3}\right)$ and methylene $\left(-\mathrm{CH}_{2}\right)$ groups in ODT. Qualitatively, these contact angles are similar to that observed for functional groups of $\mathrm{NH}_{2}$ and $\mathrm{CH}_{3}$ groups on $\mathrm{Au}$ [17].

\subsection{Reflection Absorption Infrared Spectroscopy (RAIRS)}

The FTIR spectrum for APTES on Si is shown in Figure 2a. A strong primary amine band is observed at $1575 \mathrm{~cm}^{-1}$ [19].

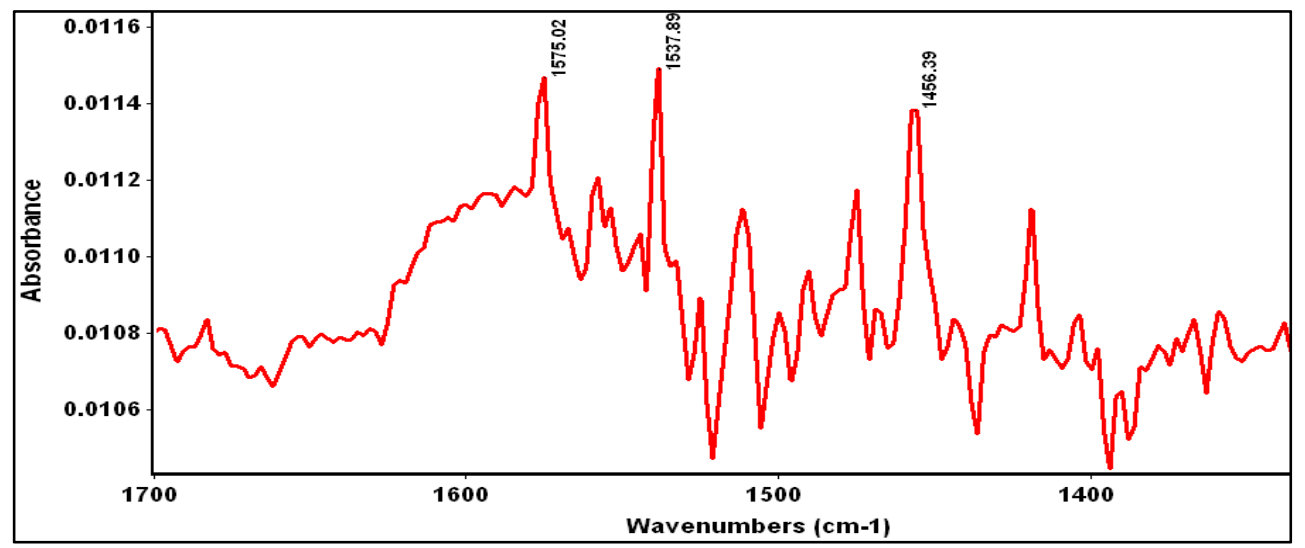

(a)

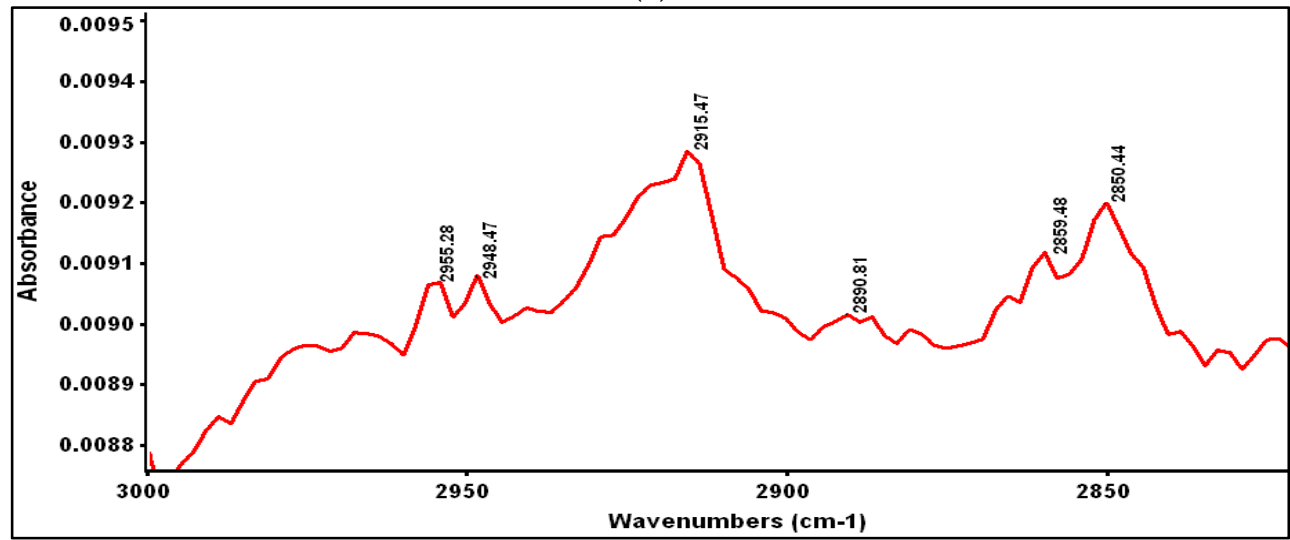

(b)

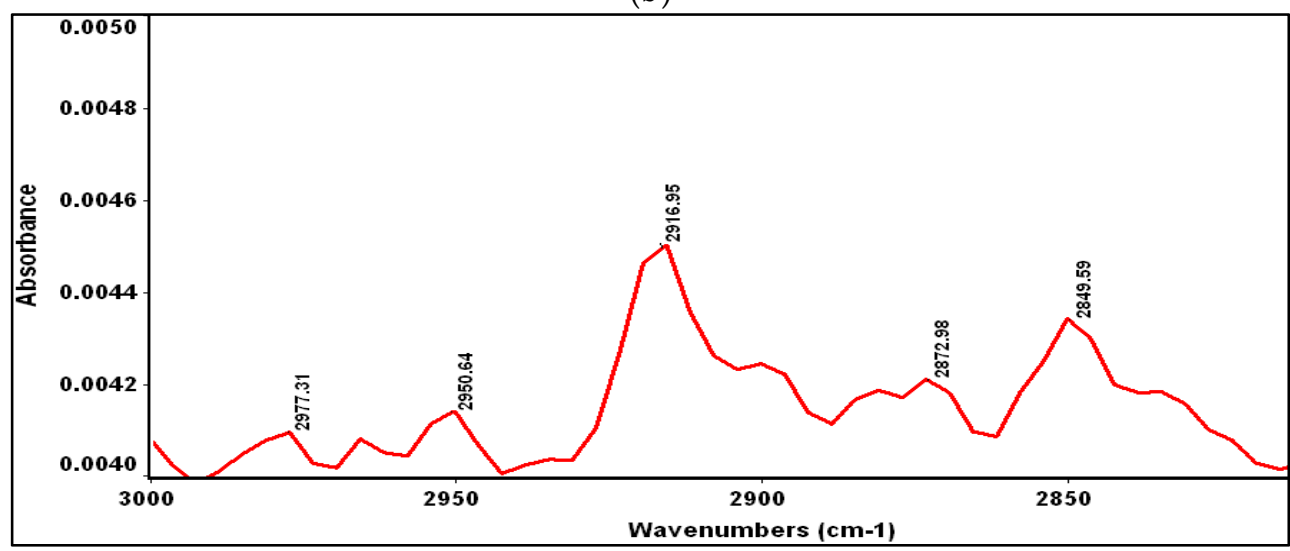

(c)

Figure 2. RAIRS spectra of (a) APTES $\left(-\mathrm{NH}_{2}\right)$ on silicon $(\mathrm{Si})$; (b) ODT $\left(-\mathrm{CH}_{3}\right)$ on GaAs and (c) ODT $\left(-\mathrm{CH}_{3}\right)$ on ITO. 
This is similar to that reported by Kim et al. for their studies with APTES on Si. By analogy, the modes at 1575 and $1460 \mathrm{~cm}^{-1}$ can be attributed to the surface amino groups. Similarly, the bending mode of the methylene group adjacent to $\mathrm{Si}\left(-\mathrm{Si}-\mathrm{CH}_{2}-\right)$ is observed around $1420 \mathrm{~cm}^{-1}$. The RAIR spectra of ODT SAM on GaAs and ITO are shown in Figure 2b,c. The asymmetric and symmetric bands of methylene $\left(-\mathrm{CH}_{2}\right)$ stretches are observed at 2917 and $2850 \mathrm{~cm}^{-1}$ (Figure 2), while the asymmetric C-H stretching mode of $\mathrm{CH}_{3}$ is observed at $2964 \mathrm{~cm}^{-1}$ on GaAs and ITO [20]. These IR (Table 1) and contact angle data are remarkably similar to alkanethiol SAMs formed on noble metals.

Table 1. Comparison of peak positions for ODT stretching modes in crystalline and liquid states, and SAMs on Au, ITO and GaAs.

\begin{tabular}{|c|c|c|c|c|c|c|}
\hline \multirow[t]{2}{*}{$\begin{array}{c}\text { Structural } \\
\text { Group }\end{array}$} & \multirow{2}{*}{$\begin{array}{l}\text { C-H } \\
\text { Stretching } \\
\text { Mode }\end{array}$} & \multicolumn{2}{|c|}{$\begin{array}{l}\text { Peak Positions of } \\
\text { Crystalline and Liquid } \\
\text { States }[21], \mathrm{cm}^{-1}\end{array}$} & \multirow{2}{*}{$\begin{array}{l}\text { Peak Positions for } \\
\text { ODT Adsorbed on } \\
\text { Gold [21], cm }\end{array}$} & \multirow{2}{*}{$\begin{array}{l}\text { Peak Positions for } \\
\text { ODT Adsorbed on } \\
\text { ITO [20], } \mathrm{cm}^{-1}\end{array}$} & \multirow{2}{*}{$\begin{array}{l}\text { Peak Positions for } \\
\text { ODT Adsorbed on } \\
\text { GaAs, } \mathrm{cm}^{-1}\end{array}$} \\
\hline & & Crystalline & Liquid & & & \\
\hline \multirow{2}{*}{$-\mathrm{CH}_{2}-$} & $v_{a}$ & 2918 & 2924 & 2917 & 2917 & 2915 \\
\hline & $v_{\mathrm{s}}$ & 2851 & 2855 & 2850 & 2849 & 2850 \\
\hline $\mathrm{CH}_{3-}$ & $v_{a}$ & - & - & 2965 & 2964 & 2964 \\
\hline
\end{tabular}

\subsection{Cell Morphology}

Figure 3a-f shows HDF morphology cultured on different SAM-modified substrates after $48 \mathrm{~h}$. For ITO (Figure 3e) and ITO modified with ODT $\left(-\mathrm{CH}_{3}\right)$ (Figure 3f) the nuclei, nucleoli, and cytoplasmic processes are very prominent compared with modified and unmodified Si and GaAs substrates. Very few cells are observed on Si (Figure 3a), Si-APTES (Figure 3b) and GaAs-ODT (Figure 3d) appear with the nucleus (enclosing the nucleoli), while no cells were observed on GaAs (Figure 3c), suggesting the occurrence of cell death on this substrate.

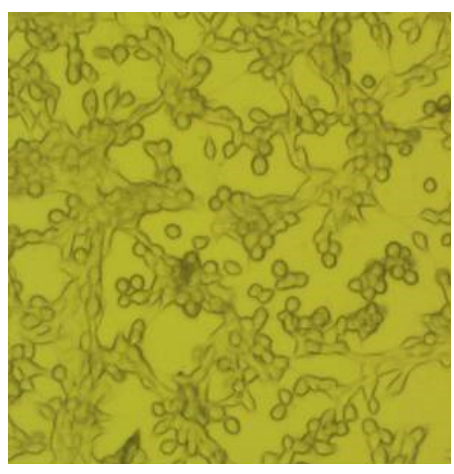

(a)

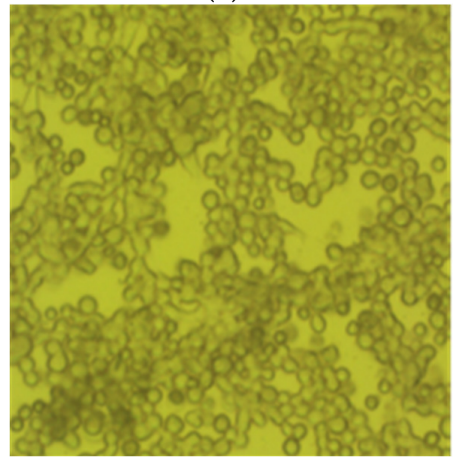

(d)

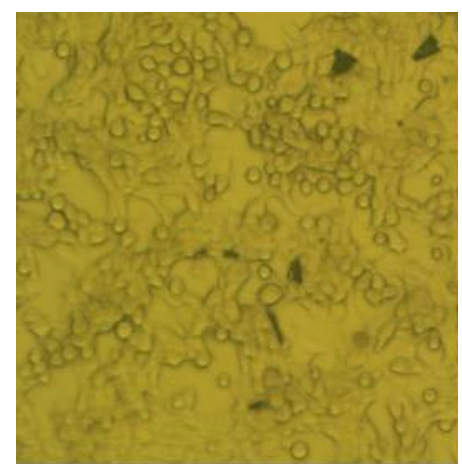

(b)

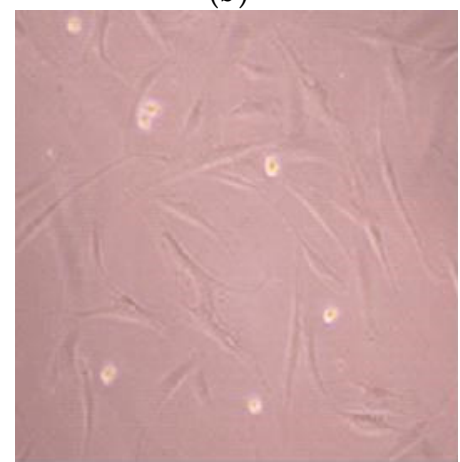

(e)

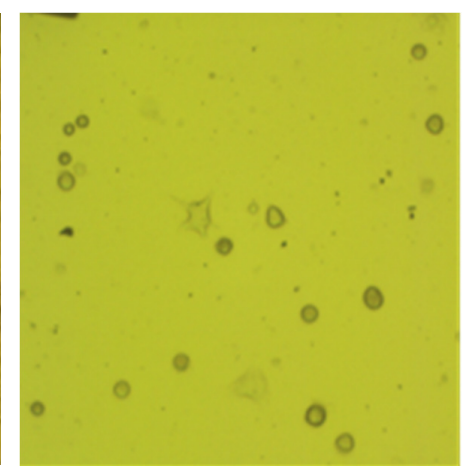

(c)

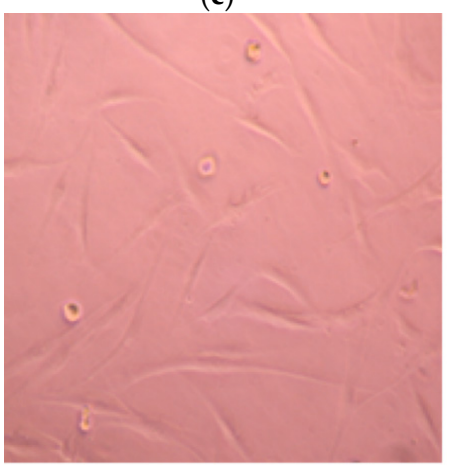

(f)

Figure 3. Phase contrast images of HDFs on (a) $\mathrm{Si}$; (b) Si-APTES (-NH2 end group); (c) GaAs; (d) GaAs-ODT ( $-\mathrm{CH}_{3}$ end group); (e) ITO and (f) ITO-ODT $\left(-\mathrm{CH}_{3}\right.$ end group) after $48 \mathrm{~h}$ (Bar represents $10 \mu \mathrm{m})$. 
The cell adhesion and cell flattening observed were predominantly on $\left(-\mathrm{CH}_{3}\right)$ modified ITO substrates indicates that the HDF cells quickly adapted to this surface compared to other end group-modified surfaces. Furthermore, fibroblast spindle-shaped morphology was only observed on ITO and ITO-ODT (- $\mathrm{CH}_{3}$ end group) substrates. Interestingly, HDF cell attachment and morphology observed on GaAs-ODT was clearly different to the cell behavior observed on ITO-ODT, even though the film deposited in both cases was the same. ODT addition to the GaAs and ITO substrate is made by the formation of sulphide bonds leaving the hydrocarbon end free, forming a hydrophobic surface. The manner of SAM deposition on GaAs and ITO were different and it is possible that processing may be responsible for the difference in HDF behavior. After one week in culture, cell growth on SAM-modified Si and ITO were comparable (see proliferation data).

\subsection{Cell Viability}

The viability of HDFs cultured on SAM-modified substrates after $48 \mathrm{~h}$ of seeding was assessed using the two-color Live/Dead ${ }^{\circledR}$ fluorescence assay.

ITO substrates were observed under fluorescent microscopy while opaque substrates ( $\mathrm{Si}, \mathrm{GaAs}$ ) were viewed with an optical microscope equipped with filters for Calcein and Ethidium bromide.

Viability analysis performed on HDFs cultured on GaAs and GaAs modified with ODT showed extremely low cellular viability on GaAs (Figure 4a) compared to GaAs-ODT (Figure 4b). The low cellular viability is most likely due to arsenic leakage in the media during culture, which is toxic, causing cell death. The viability of cells notably increased on GaAs-ODT due to the presence of ODT monolayer, which seems to protect the surface from exposure to arsenic to a certain extent. In contrast to GaAs and GaAs-ODT, studies on Si and Si-APTES (Figure 4c,d) indicate good cellular viability on both the surfaces, with Si-APTES showing a comparatively better response. This result indicates the supportive nature of $\mathrm{Si}$. The amino $\left(-\mathrm{NH}_{2}\right)$ group provides a better environment for cell attachment and growth.

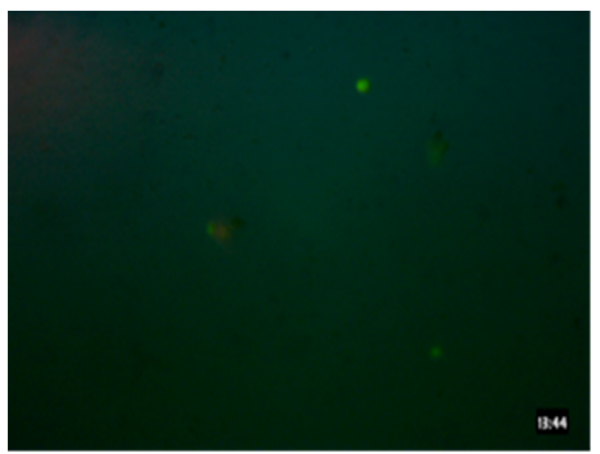

(a)

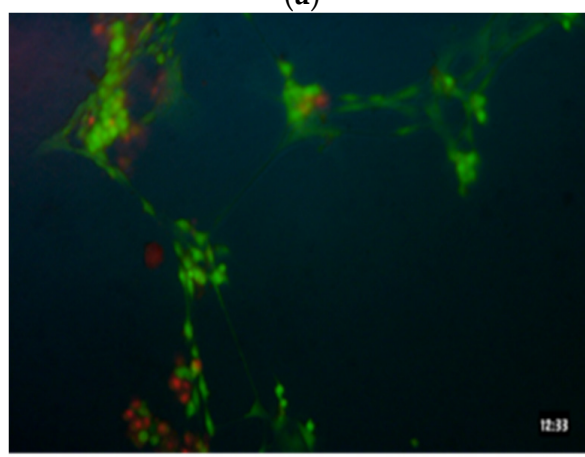

(c)

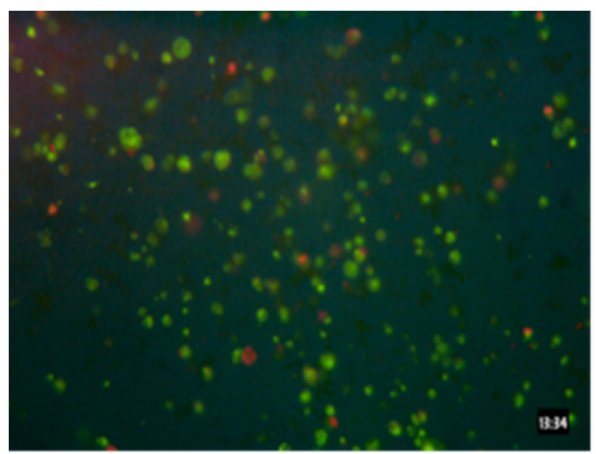

(b)

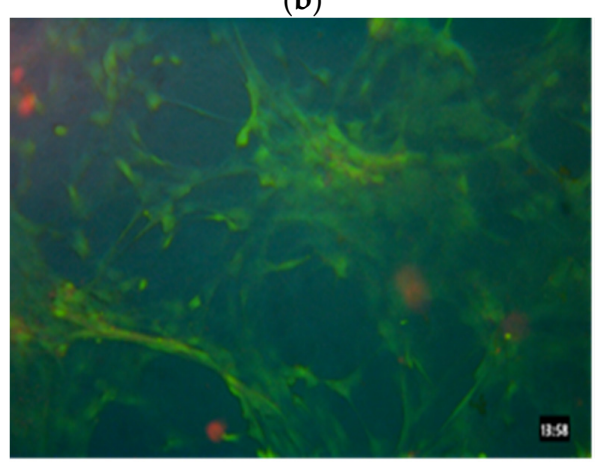

(d)

Figure 4. Cellular viability observed by LIVE/DEAD ${ }^{\circledR}$ analysis on (a) GaAs; (b) GaAs-ODT (-CH 3 ); (c) $\mathrm{Si}$ and (d) Si-APTES $\left(-\mathrm{NH}_{2}\right)$ after $48 \mathrm{~h}$ (Bar represents $\left.10 \mu \mathrm{m}\right)$. 
Similar viability results were observed on ITO and ITO-modified with ODT (Figure 5). Visual observations showed that cell spreading was greatest on ITO-ODT as compared with all other substrates. Cell viability on all these substrates also followed this trend: ITO-ODT $>$ ITO $>$ Si-APTES $>$ $\mathrm{Si}>\mathrm{GaAs}-\mathrm{ODT}>\mathrm{GaAs}$.

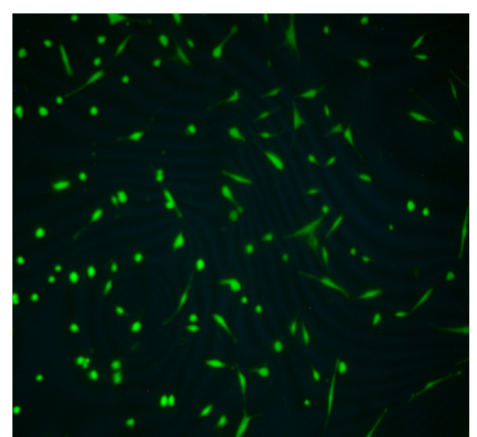

(a)

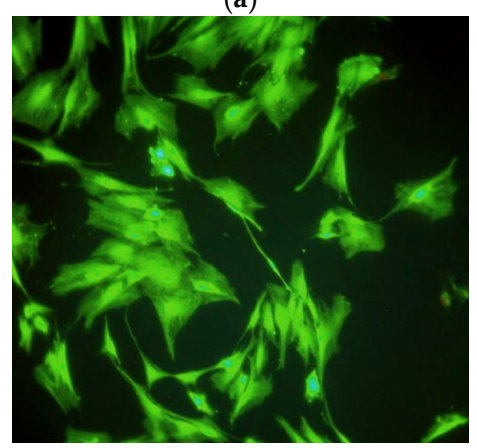

(c)

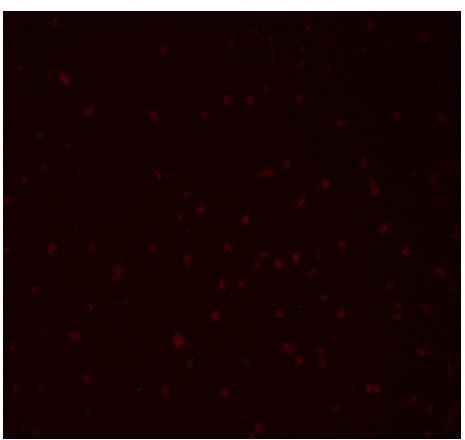

(b)

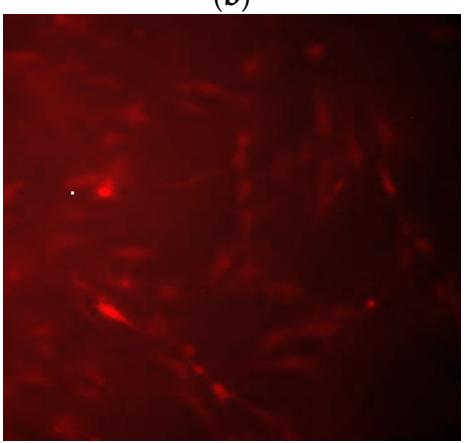

(d)

Figure 5. Cellular viability observed by LIVE/DEAD ${ }^{\circledR}$ analysis.(a) Live cells on ITO; (b) Dead cells on ITO; (c) Live cells on ITO-ODT and (d) Dead cells on ITO-ODT after $48 \mathrm{~h}$ (Bar represents $10 \mu \mathrm{m}$ ).

\subsection{Cell Proliferation}

Proliferation of the cells was determined using MTT assays. Cells were seeded at a density of 2000 cells $/ \mathrm{cm}^{2}$ and proliferation was determined after 3, 5 and 7 days of culture. Figure 6 shows an increased absorbance at $570 \mathrm{~nm}$ after 5 days in vitro (DIV) compared with 3 DIV indicating the proliferation of the cells.

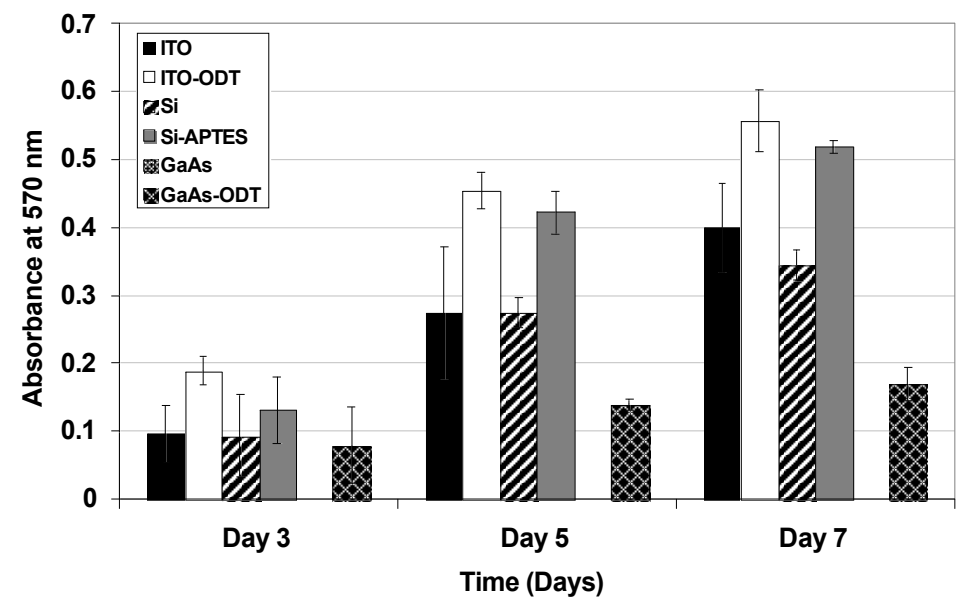

Figure 6. Proliferation of HDFs on SAM-modified and unmodified Si, GaAs and ITO surfaces after 3, 5 and 7 DIV. Data represent the mean \pm S.D, $n=3$. 
After 3 DIV, no cells were observed on GaAs surface suggesting cell death due to arsenic leakage in the media. Proliferation was highest for SAM-modified surfaces compared to other surfaces after 5 and 7 DIV. Higher cell densities were observed on ODT modified ITO (ITO- $\left.\mathrm{CH}_{3}\right)$ followed by APTES modified $\mathrm{Si}\left(\mathrm{Si}-\mathrm{NH}_{2}\right)$. Among the unmodified surfaces, proliferation was observed on both ITO and $\mathrm{Si}$ and they were not significantly different. For SAM-modified surfaces, cell proliferation was least on ODT modified GaAs (GaAs- $\left.\mathrm{CH}_{3}\right)$. There was only a small increase in cell density from 3 DIV to 7 DIV. This result clearly shows that protection of the GaAs surface by a monolayer of organic molecules does prevent arsenic leakage to a certain extent enabling the cells to attach and proliferate for a certain period of time (in this case, for seven days).

\subsection{Immunocytochemical Analysis}

Immunocytochemistry (ICC) analysis was conducted using Type-I collagen monoclonal antibodies. Figure 7 illustrate HDFs on GaAs, GaAs-ODT, Si, Si-APTES, ITO and ITO-ODT respectively. The brown reaction indicates that an antigen-antibody complex has formed yielding a positive immunoreaction. The ICC analysis indicated that HDF's cultured on ITO, ITO-ODT, Si, Si-APTES and GaAs-ODT, with the exception of GaAs, were positive for Type I collagen. The identification of intracellular Type-I collagen suggests that HDFs maintained their phenotype and were synthetically active.

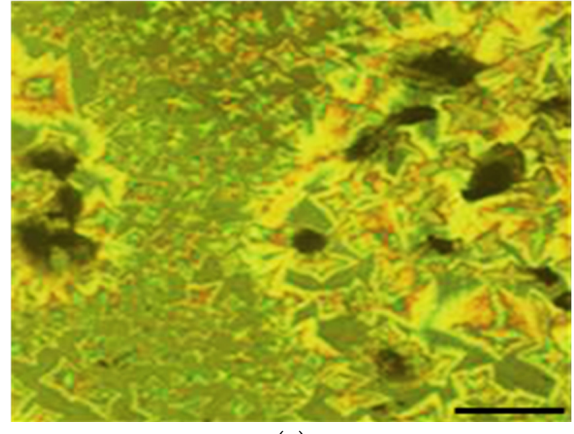

(a)

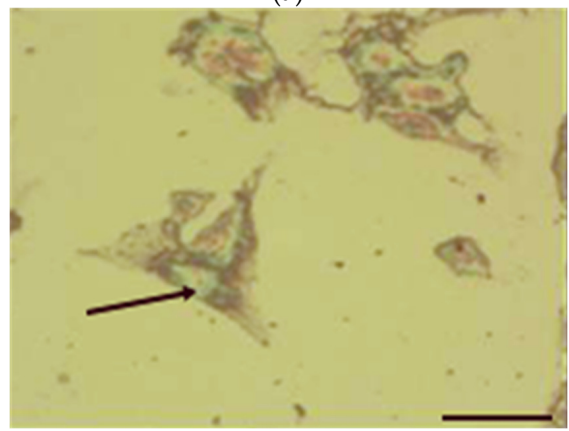

(c)

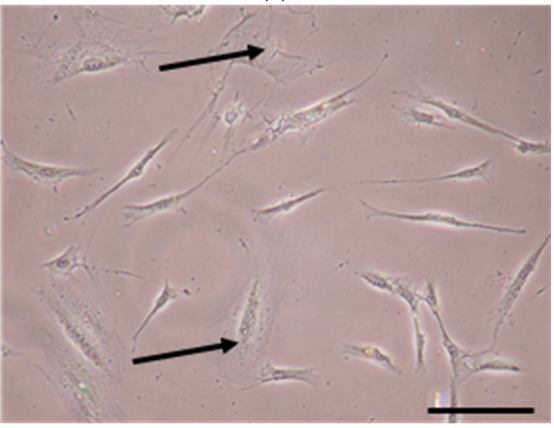

(e)

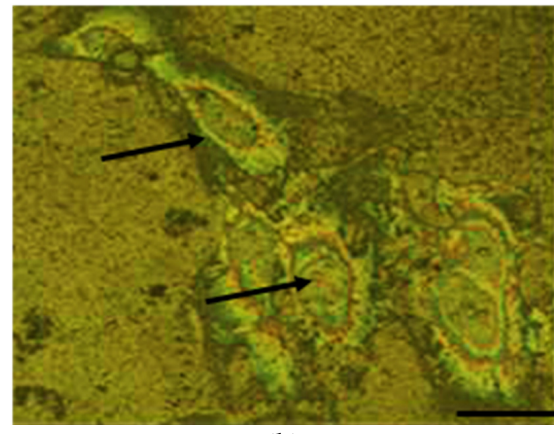

(b)

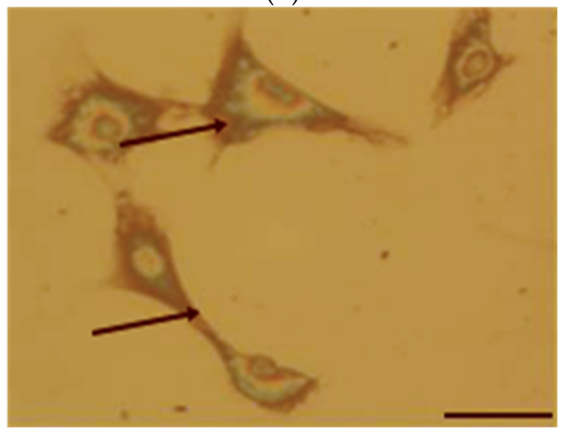

(d)

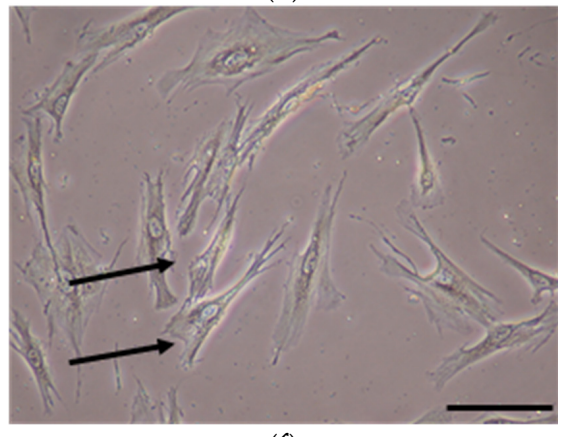

(f)

Figure 7. Immunohistochemical detection of Type-I Collagen after $48 \mathrm{~h}$ in culture. (b) GaAs-ODT; (c) Si; and (d) Si-APTES; (e) ITO; and (f) ITO-ODT (Bar represents $40 \mu \mathrm{m}$ ). 
Surface modification of industry-relevant substrates with SAMs is a promising technique for developing biocompatible and bioactive substrates. The strength of this technique lies in the fact that a monolayer of molecules can change the entire role of a substrate, from toxic to biocompatible (partially in the case of SAM-modified GaAs as demonstrated here). As the surface properties of a SAM are different from those of the bulk substrate, surface modification provide development of a more diverse set of surface chemistries through chemically altering reactive terminal groups, thus permitting development of substrates with diverse surface properties. Many approaches have been investigated to obtain predictable surface chemistries of biomaterials that either alter or inhibit specific cell functions [22-30]. To date, most of the cell culture studies have been performed on Au and SAM-modified Au surfaces [6-8,14,23-28]. Limited studies have been directed on other surfaces of importance such as indium tin oxide (ITO) [31,32], silicon (Si) [18], and gallium arsenide (GaAs) [33].

In this study, the behavior of HDF was assessed on SAM-modified and unmodified substrates of ITO, $\mathrm{Si}$, and GaAS. The results from our cytotoxicity, proliferation and functionality studies indicate that HDFs proliferated well on all SAM substrates and exhibited the characteristic long spindle-shaped fibroblast morphology. The HDFs exhibited no visible signs of stress or cytoplasmic vacuolation. HDFs also maintained their phenotype, and were synthetically active. All the substrates, except GaAs, encouraged HDFs to attach, grow, and maintain cell functionality. Initial adhesion of proteins from the media on the SAMs may be responsible for the observed cell behavior. In the case of ITO-ODT, we assume that the hydrophobic end group $\left(-\mathrm{CH}_{3}\right)$ couples with the hydrophobic part of the unfolding protein releasing many hydrophobically structured water molecules and leading to the large entropy gain for the system $[34,35]$. In the case of amino groups, cell proliferation has been attributed to the translocation and organization of the cells $\beta_{1}$ integrin to fibronectin deposited on these groups $[18,36,37]$.

The results from our studies also provide strong evidence that cellular attachment to surfaces is influenced by small changes in the substratum chemical composition and molecular structure. It has been demonstrated that HDFs exhibit different responses to specific surface chemistries when cultured under similar conditions. Additionally, the influence of the substrate alone revealed that the HDF cells attached better on indium tin oxide substrates compared to all other unmodified substrates.

\section{Conclusions}

The results from our study suggest that the SAM-modified Si, GaAs and ITO substrates may be used as a model to study the interaction of cultured cells with biomaterials and for obtaining qualitative and quantitative information. The results obtained from the HDF studies can also be extended to other mammalian cell types and stem cells. Furthermore, the materials bulk properties such as conducting nature of ITO can be used to make microelectrode arrays for neuronal studies, and semi-conducting nature of Si-biological entities can be integrated to the microelectronics and the clinical usage can be explored more using surface modification strategies.

Acknowledgments: We thank the Louisiana Governor's Biotechnology Initiative and NSF-EPSCoR for funding this work. We thank Vishwanath Deshmane for his help in preparing this manuscript.

Author Contributions: Debasish Kuila and David K. Mills conceived and designed the experiments; Rajendra K. Aithal, Deepak P. Kumaraswamy, and Amber T. Doss performed the experiments; Rajendra K. Aithal and Deepak P. Kumaraswamy also helped to analyze the data; Rajendra K. Aithal, David K. Mills and Debasish Kuila wrote the paper.

Conflicts of Interest: The authors declare no conflict of interest.

\section{References}

1. Jauregui, H.O. Cell adhesion to biomaterials. The role of several extracellular matrix components in the attachment of non-transformed fibroblasts and parenchymal cells. ASAIO Trans. Am. Soc. Artif. Intern. Organs. 1986, 33, 66-74. [CrossRef] 
2. Asbill, C.; Kim, N.; El-Kattan, A.; Creek, K.; Wertz, P.; Michniak, B. Evaluation of a human bio-engineered skin equivalent for drug permeation studies. Pharm. Res. 2000, 17, 1092-1097. [CrossRef] [PubMed]

3. Blaha, M.; Bowers, W.; Kohl, J.; DuBose, D.; Walker, J.; Alkhyyat, A.; Wong, G. Effects of cees on inflammatory mediators, heat shock protein 70A, histology and ultrastructure in two skin models. J. Appl. Toxicol. 2000, 20, S101-S108. [CrossRef]

4. Lee, J.K.; Kim, D.B.; Kim, J.I.; Kim, P.Y. In vitro cytotoxicity tests on cultured human skin fibroblasts to predict skin irritation potential of surfactants. Toxicol. Vitro 2000, 14, 345-349. [CrossRef]

5. Nakamura, M.; Sato, N.; Chikama, T.; Hasegawa, Y.; Nishida, T. Hyaluronan facilitates corneal epithelial wound healing in diabetic rats. Exp. Eye Res. 1997, 64, 1043-1050. [CrossRef] [PubMed]

6. Cooper, E.; Parker, L.; Scotchford, C.A.; Downes, S.; Leggett, G.J.; Parker, T.L. The effect of alkyl chain length and terminal group chemistry on the attachment and growth of murine 3T3 fibroblasts and primary human osteoblasts on self-assembled monolayers of alkanethiols on gold. J. Mater. Chem. 2000, 10, 133-139. [CrossRef]

7. Alberts, B.; Johnson, A.; Lewis, J.; Raff, M.; Roberts, K.; Walter, P. Molecular Biology of the Cell; Garland Science: New York, NY, USA, 2002; Volume 4, pp. 1090-1113.

8. McClary, K.B.; Ugarova, T.; Grainger, D.W. Modulating fibroblast adhesion, spreading, and proliferation using self-assembled monolayer films of alkylthiolates on gold. J. Biomed. Mater. Res. 2000, 50, 428-439. [CrossRef]

9. Mrksich, M. What can surface chemistry do for cell biology? Curr. Opin. Chem. Biol. 2002, 6, 794-797. [CrossRef]

10. Van Kooten, T.; Schakenraad, J.; van der Mei, H.; Busscher, H. Influence of substratum wettability on the strength of adhesion of human fibroblasts. Biomaterials 1992, 13, 897-904. [CrossRef]

11. Absolom, D.R.; Hawthorn, L.A.; Chang, G. Endothelialization of polymer surfaces. J. Biomed. Mater. Res. 1988, 22, 271-285. [CrossRef] [PubMed]

12. Horbett, T.A.; Schway, M.B. Correlations between mouse 3 T3 cell spreading and serum fibronectin adsorption on glass and hydroxyethylmethacrylate-ethylmethacrylate copolymers. J. Biomed. Mater. Res. 1988, 22, 763-793. [CrossRef] [PubMed]

13. Scotchford, C.A.; Cooper, E.; Leggett, G.J.; Downes, S. Growth of human osteoblast-like cells on alkanethiol on gold self-assembled monolayers: The effect of surface chemistry. J. Biomed. Mater. Res. 1998, 41, 431-442. [CrossRef]

14. Cooper, E.; Wiggs, R.; Hutt, D.A.; Parker, L.; Leggett, G.J.; Parker, T.L. Rates of attachment of fibroblasts to self-assembled monolayers formed by the adsorption of alkylthiols onto gold surfaces. J. Mater. Chem. 1997, 7, 435-441. [CrossRef]

15. Daw, R.; Brook, I.M.; Jane Devlin, A.; Short, R.D.; Cooper, E.; Leggett, G.J. A comparative study of cell attachment to self assembled monolayers and plasma polymers. J. Mater. Chem. 1998, 8, 2583-2584. [CrossRef]

16. Lin, M.; Wang, H.; Ruan, C.; Xing, J.; Wang, J.; Li, Y.; Wang, Y.; Luo, Y. Adsorption force of fibronectin on various surface chemistries and its vital role in osteoblast adhesion. Biomacromolecules 2015, 16, 973-984. [CrossRef] [PubMed]

17. Arima, Y.; Iwata, H. Preferential adsorption of cell adhesive proteins from complex media on self-assembled monolayers and its effect on subsequent cell adhesion. Acta Biomater. 2015, 26, 72-81. [CrossRef] [PubMed]

18. Faucheux, N.; Schweiss, R.; Lützow, K.; Werner, C.; Groth, T. Self-assembled monolayers with different terminating groups as model substrates for cell adhesion studies. Biomaterials 2004, 25, 2721-2730. [CrossRef] [PubMed]

19. Kim, J.; Seidler, P.; Wan, L.S.; Fill, C. Formation, structure, and reactivity of amino-terminated organic films on silicon substrates. J. Colloid Interface Sci. 2009, 329, 114-119. [CrossRef] [PubMed]

20. Kolipaka, S.; Aithal, R.K.; Kuila, D. Fabrication and characterization of an indium tin oxide-octadecanethiol-aluminum junction for molecular electronics. Appl. Phys. Lett. 2006, 88. [CrossRef]

21. Laibinis, P.E.; Whitesides, G.M.; Allara, D.L.; Tao, Y.T.; Parikh, A.N.; Nuzzo, R.G. Comparison of the structures and wetting properties of self-assembled monolayers of $n$-alkanethiols on the coinage metal surfaces, copper, silver, and gold. J. Am. Chem. Soc. 1991, 113, 7152-7167. [CrossRef] 
22. Mrksich, M. A surface chemistry approach to studying cell adhesion. Chem. Soc. Rev. 2000, 29, $267-273$. [CrossRef]

23. Mrksich, M.; Chen, C.S.; Xia, Y.; Dike, L.E.; Ingber, D.E.; Whitesides, G.M. Controlling cell attachment on contoured surfaces with self-assembled monolayers of alkanethiolates on gold. Proc. Natl. Acad. Sci. USA 1996, 93, 10775-10778. [CrossRef] [PubMed]

24. Mrksich, M.; Whitesides, G.M. Using self-assembled monolayers to understand the interactions of man-made surfaces with proteins and cells. Annu. Rev. Biophys. Biomol. Struct. 1996, 25, 55-78. [CrossRef] [PubMed]

25. Mrksich, M.; Dike, L.E.; Tien, J.; Ingber, D.E.; Whitesides, G.M. Using microcontact printing to pattern the attachment of mammalian cells to self-assembled monolayers of alkanethiolates on transparent films of gold and silver. Exp. Cell Res. 1997, 235, 305-313. [CrossRef] [PubMed]

26. Roberts, C.; Chen, C.S.; Mrksich, M.; Martichonok, V.; Ingber, D.E.; Whitesides, G.M. Using mixed self-assembled monolayers presenting $\mathrm{rgd}$ and (EG) ${ }_{3} \mathrm{OH}$ groups to characterize long-term attachment of bovine capillary endothelial cells to surfaces. J. Am. Chem. Soc. 1998, 120, 6548-6555. [CrossRef]

27. Kato, M.; Mrksich, M. Rewiring cell adhesion. J. Am. Chem. Soc. 2004, 126, 6504-6505. [CrossRef] [PubMed]

28. Ostuni, E.; Yan, L.; Whitesides, G.M. The interaction of proteins and cells with self-assembled monolayers of alkanethiolates on gold and silver. Colloids Surf. B Biointerfaces 1999, 15, 3-30. [CrossRef]

29. Chen, C.S.; Mrksich, M.; Huang, S.; Whitesides, G.M.; Ingber, D.E. Micropatterned surfaces for control of cell shape, position, and function. Biotechnol. Prog. 1998, 14, 356-363. [CrossRef] [PubMed]

30. Jiang, X.; Ferrigno, R.; Mrksich, M.; Whitesides, G.M. Electrochemical desorption of self-assembled monolayers noninvasively releases patterned cells from geometrical confinements. J. Am. Chem. Soc. 2003, 125, 2366-2367. [CrossRef] [PubMed]

31. Bieberich, E.; Guiseppi-Elie, A. Neuronal differentiation and synapse formation of PC12 and embryonic stem cells on interdigitated microelectrode arrays: Contact structures for neuron-to-electrode signal transmission (nest). Biosens. Bioelectron. 2004, 19, 923-931. [CrossRef] [PubMed]

32. Pulsipher, A.; Westcott, N.P.; Luo, W.; Yousaf, M.N. Rapid microfluidic generation of patterned aldehydes from hydroxy-terminated self-assembled monolayers for ligand and cell immobilization on optically transparent indium tin oxide surfaces. Adv. Mater. 2009, 21, 3082-3086. [CrossRef]

33. Kirchner, C.; George, M.; Stein, B.; Parak, W.J.; Gaub, H.E.; Seitz, M. Corrosion protection and long-term chemical functionalization of gallium arsenide in an aqueous environment. Adv. Funct. Mater. 2002, 12, 266-276. [CrossRef]

34. Hoffman, A.S. Letter to the editor: A general classification scheme for "hydrophilic" and "hydrophobic" biomaterial surfaces. J. Biomed. Mater. Res. 1986, 20, 9-11. [CrossRef] [PubMed]

35. Hoffman, A.S. Non-fouling surface technologies. J. Biomater. Sci. Polym. Ed. 1999, 10, 1011-1014. [CrossRef] [PubMed]

36. Altankov, G.; Groth, T.; Krasteva, N.; Albrecht, W.; Paul, D. Morphological evidence for a different fibronectin receptor organization and function during fibroblast adhesion on hydrophilic and hydrophobic glass substrata. J. Biomater. Sci. Polym. Ed. 1997, 8, 721-740. [CrossRef] [PubMed]

37. Sottile, J.; Hocking, D.C.; Swiatek, P.J. Fibronectin matrix assembly enhances adhesion-dependent cell growth. J. Cell Sci. 1998, 111, 2933-2943. [PubMed]

(C) 2016 by the authors; licensee MDPI, Basel, Switzerland. This article is an open access article distributed under the terms and conditions of the Creative Commons by Attribution (CC-BY) license (http://creativecommons.org/licenses/by/4.0/). 